\title{
DEVELOPMENT, EVALUATION AND RP-HPLC METHOD FOR SIMULTANEOUS ESTIMATION OF QUERCETIN, ELLAGIC ACID AND KAEMPFEROL IN A POLYHERBAL FORMULATION
}

\author{
SHALINI K. a ILANGO K. ${ }^{*}$
}

aDivision of Pharmacognosy and Phytochemistry, Interdisciplinary Institute of Indian System of Medicine (IIISM), SRM Institute of Science and Technology, Kattankulathur - 603 203, Chengalpattu (Dt), Tamil Nadu, India, b* Department of Pharmaceutical Chemistry, SRM College of Pharmacy, SRM Institute of Science and Technology, Kattankulathur - 603 203, Chengalpattu (Dt), Tamil Nadu, India

Email: ilangok1@srmist.edu.in

Received: 06 Feb 2021, Revised and Accepted: 27 Mar 2021

\section{ABSTRACT}

Objective: The current study was planned to develop polyherbal tablet formulation, standardization and evaluation for mitigating the symptoms of polycystic ovarian syndrome (PCOS). To control the issue of PCOS in women by the utilization of newly developed polyherbal tablet formulation.

Methods: The polyherbal tablets were prepared using a hydroalcoholic extract of the selected medicinal plants viz. Asparagus racemosus, Bauhinia variegata, Caesalpinia bonducella, Saraca asoca, and Symplocos racemosa with the help of a super disintegrant addition technique using crospovidone, kyron T-314 and pregelatinized starch in various percentages. Evaluation assessments such as pre-formulation studies, weight variation, hardness, friability, thickness, disintegration, IR compatibility and simultaneous estimation of quercetin, ellagic acid and kaempferol by RP-HPLC method were done.

Results: The results reveal that preformulation and evaluation parameters were satisfactory and found to be within an acceptable limit. The Fourier transform infrared spectroscopy (FTIR) compatibility displays no chemical interaction amongst the hydroalcoholic extract of polyherbal formulation and excipients. In simultaneous estimation, the retention time of quercetin, ellagic acid, and kaempferol were found to be $4.86,6.96$ and $10.01 \mathrm{~min}$ respectively. The linearity of quercetin, ellagic acid and kaempferol were found in the range of $0-200 \mu \mathrm{g} / \mathrm{ml}$ with correlation coefficients $\left(\mathrm{R}^{2}>0.997\right)$ within the tested ranges. The LOD and LOQ values of quercetin, ellagic acid and kaempferol were found to be $11.86,2.63,5.28 \mu \mathrm{g} / \mathrm{ml}$ and $35.95,7.98,16.00 \mu \mathrm{g} / \mathrm{ml}$ respectively. The \% RSD values were found to be less than 2 showed the optimized method is precise.

Conclusion: To conclude, the prepared polyherbal tablet and its quality control analysis revealed satisfactory pharmaceutical properties that fulfill within the limits of pharmacopeial standards. The RP-HPLC method for simultaneous estimation of quercetin, ellagic acid and kaempferol were simple, precise, accurate and consistent for the quantitative analysis and quality control examination of herbal formulations.

Keywords: Standardization, Super disintegrant, Compatibility, Simultaneous, Quantitative

(C) 2021 The Authors. Published by Innovare Academic Sciences Pvt Ltd. This is an open access article under the CC BY license (https://creativecommons.org/licenses/by/4.0/) DOI: https://dx.doi.org/10.22159/ijap.2021v13i3.41028. Journal homepage: https://innovareacademics.in/journals/index.php/ijap

\section{INTRODUCTION}

Herbal medicines are significant wellsprings of medical care for humanity over the centuries. World Health Organisation (WHO) reports $80 \%$ of the world population depends on medications that are of natural origin $[1,2]$. The mixture of medicinal herbs frequently produces a hopeful impact in the treatment of sicknesses over a single medication [3]. The polyherbal formulation in an oral route is best that allows for individual dosing are easy to swallow and long stability [4]. Due to poor quality control, it isn't possible for the greater part of the herbal drugs to demonstrate their effectiveness in clinical practice. Thinking about the clinical utilization of these herbal drugs, the attention has been moved to the ease of medication rather than the conventional dosage form, which diminishes patient compliance [5]. Standardization and quality control of plant-based herbal medication by utilizing modern apparatus and utilization of suitable standards is constantly emphasized by WHO [6]. Quality control of herbal medication is a significant process of the pharmaceutical companies, which is mentioned as all should be embraced to promise the purity and uniformity of marketed pharmaceuticals [7]. The development of this polyherbal formulation into a suitable drug delivery system in the form of a tablet was looked to be of suitable pharmacopeial quality and would have comparable release profiles of the conventional dosage form. The current study was completed to standardize the extract and formulate a suitable dosage form (tablet dosage form). Tablet coating is a significant unit process in the manufacturing of solid oral dosage forms [8]. In simultaneous estimation, we have established a simple, optimized and validated RP-HPLC technique for the standardization of a polyherbal formulation utilizing three chemical markers specifically quercetin, ellagic acid and kaempferol. The simultaneous estimation was validated as per the ICH guidelines. This novel validated technique may be utilized in the industry as well as in academia [9].<smiles>O=c1c(O)c(-c2ccc(O)c(O)c2)oc2cc(O)cc(O)c12</smiles>

a<smiles>O=c1oc2c(O)c(O)c(O)c3c(=O)oc4c(O)c(O)cc1c4c23</smiles>

b<smiles>O=c1c(O)c(-c2ccc(O)cc2)oc2cc(O)cc(O)c12</smiles>

c

Fig. 1: Chemical structure of (a) Quercetin (b) Ellagic acid (c) Kaempferol 


\section{MATERIALS AND METHODS}

\section{Collection and authentication of plant materials}

All the ingredients of the Polyherbal formulation are collect and purchased from different parts of Chennai. Their authentications were confirmed by Prof. P. Jayaraman (Botanist), Plant Anatomy Research Centre, Tambaram, Chennai, Tamil Nadu, India with a reference number of Asparagus racemosus, Bauhinia variegata, Caesalpinia bonducella, Saraca asoca, and Symplocos racemosa was PARC/2021/4431-4435 respectively.

\section{Preparation of extract}

All the selected medicinal plant parts were cleaned by utilizing a sterilized fabric cloth to get rid of dirt and via air, blustering to eliminate minute sand particles. Each $1000 \mathrm{mg}$ of a polyherbal formulation contains a different quantity of Asparagus racemosus (root), Bauhinia variegata (wood), Caesalpinia bonducella (seed kernel), Saraca asoca (bark), and Symplocos racemosa (bark). Each plant material was size reduced using a cutter mill. After that sieved separately all the plant materials using sieve no 60 . Each blended and dried powder of individual plant materials was weighed in the required quantity. After that, all the individual powder was macerated with hydroalcoholic solvent [10] (30:70) with frequent stirring for $72 \mathrm{~h}$. After $72 \mathrm{~h}$ the suspensions were shifted through a fine muslin fabric cloth and the collected filtrate was evaporated to dryness kept at the desiccator. The yield of the collected extract was stored in an air-tight container for further analysis.

\section{Development of polyherbal formulation}

The various ingredients for polyherbal formulation are mentioned in table 1 . The measured quantities of $A$. racemosus, B. variegata, $C$. bonducella, $S$. asoca, and $S$. racemosa, pregelatinized starch, microcrystalline cellulose (MCC) 102, crospovidone, sodium lauryl sulfate (SLS), colloidal silicon dioxide alum, magnesium stearate, and kyron T-314 were mixed thoroughly using a blender. All the mixed ingredients were passed in sieve no 24 . After that $20 \mathrm{~mm}$ round punch was used for the slugging process. The slugged tablets were size reduced again passed through sieve no 12 and got the granules. The size-reduced granules were passed into sieve no 24 . In this stage, one part of magnesium stearate was added to the granules. The granules were passed into a hopper for tablet compression. Tfer punch was utilized for the direct compression of the polyherbal tablet. The compressed tablets were transferred to the coating pan. The Spray gel (white) coating suspension was sprayed over the tablets. The coating was over all the tablets was collected for further analysis and stored in an airtight container.

Table 1: The formula for the polyherbal formulation

\begin{tabular}{lll}
\hline S. No. & Ingredients & Label claim (mg) \\
\hline 1 & Asparagus racemosus (Shatavari) & 100 \\
2 & Bauhinia variegata (Kachnar) & 75 \\
3 & Caesalpinia bonducella (Kacha) & 100 \\
4 & Saraca asoca (Asoka) & 125 \\
5 & Symplocos racemosa (Lodha) & 100 \\
6 & Pregelatinized starch & 65 \\
7 & MCC 102 & 70.25 \\
8 & Crospovidone & 35 \\
9 & SLS & 21 \\
10 & Colloidal silicon dioxide alum & 3.25 \\
11 & Magnesium stearate & 6.5 \\
12 & Kyron T-314 & 49 \\
\hline
\end{tabular}

\section{Preformulation studies}

\section{Angle of repose}

The angle of repose was determined by using the funnel technique. Exactly weighed granules were taken in a funnel and the height of the funnel was adjusted in such a way that the tip of the funnel just touches the apex of the heap. The granules were permitted to flow through the funnel openly onto the surface $[11,12]$. The breadth of the powder cone was estimated and the angle of repose was determined from the accompanying formula.

$$
\tan \theta=\frac{\mathrm{h}}{\mathrm{r}}
$$

Where, $\theta=$ angle of repose, $\mathrm{h}=$ height of powder cone formed, $\mathrm{r}=$ radius of power cone formed.

\section{Bulk density}

The bulk density (BD) of the polyherbal powder mixture was determined by pouring moderately 25 gm of the polyherbal mixture through a glass funnel into a $100 \mathrm{ml}$ graduated measuring cylinder. The initial volumes involved by the sample were recorded. The bulk density was determined by utilizing the accompanying formula given as an equation.

$$
\mathrm{BD}=\frac{\text { Weight of the Powder }(\mathrm{g})}{\text { Volume occupied by the powder (ml) }}
$$

\section{Tapped density}

The tapped density (TD) of the polyherbal powder mixture was calculated by pouring moderately $25 \mathrm{gm}$ of polyherbal sample mixture through a glass funnel into a $100 \mathrm{ml}$ graduated measuring cylinder. The cylinder was tapped from the height of 2 inches until a constant volume was obtained and then the average value of formulation was reported. The final volume involved by the sample after tapping was recorded and tapped density was calculated using the following formula.

$$
\mathrm{TD}=\frac{\text { Weight of the powder }(\mathrm{g})}{\mathrm{TD} \text { volume occupied by the powder }(\mathrm{ml})}
$$

\section{Compressibility}

Carr's compressibility gives a useful empirical guide. The compressibility of the polyherbal powder mixture was calculated by comparing the bulk density and tapped density. The percentage compressibility of polyherbal tablet formulation was calculated as per the given equation.

$$
\text { Carr's index }=\frac{\text { Tabbed Density }- \text { Bulk Density }}{\text { Tabbed Density }} \times 100
$$

\section{Hausner's ratio}

It shows densification of herbal powder mixture which may result from the vibration of the feed hopper, which was calculated by using the formula given in the equation.

$$
\text { Hausner's ratio }=\frac{\text { Tabbed Density }}{\text { Bulk Density }}
$$

\section{Quality control test for polyherbal tablet formulations}

\section{Characterization of polyherbal formulation}

The general appearance included the size, shape, presence or nonappearance of color, a taste of powder, the surface of the tablet was noted. The thickness and diameter of polyherbal tablets were calculated by digital Vernier calipers and presented in $\mathrm{mm}$ [13]. 


\section{Weight variation}

Based on the pharmacopeial standard, physical tests for the optimized polyherbal tablets were achieved and average values were calculated. Mass variation was calculated by 20 polyherbal tablets separately and the average mass and percent variation of every tablet was determined.

\section{Hardness and friability}

The hardness of polyherbal tablets was calculated by taking 6 tablets utilizing a Monsanto hardness tester and the normal pressing factor $\left(\mathrm{kg} \mathrm{cm}^{-1}\right)$ applied to crush the tablet was determined. The Friability of polyherbal tablets was determined by first weighing 20 tablets after cleaning and afterward putting them in a Roche Friabilator. It was rotated at $25 \mathrm{rpm}$ in $4 \mathrm{~min}$. Subsequent cleaning the leftover mass of the polyherbal tablets was recorded and the percent friability was calculated.

\section{Disintegration}

The disintegration test of polyherbal tablets was determined by embedding one polyherbal tablet into every tube of the basket rack assembly of DT apparatus and cylinder-shaped discs were positioned on the top of tablets. The DT apparatus was worked by utilizing water as an impression fluid at $37 \pm 2{ }^{\circ} \mathrm{C}$. The DT time of polyherbal tablets was noted [14].

\section{FTIR analysis of polyherbal formulation}

Fourier transform infrared (FTIR) spectrum of selected medicinal plant extracts and polyherbal extracts was exposed to know the distinguishing proof of the compound and comparison of the drug with other excipients utilized in the formulation of polyherbal tablets [15]. The range of IR helps in the identification of a compound depends on the presence of various functional groups. Selected medicinal plant extracts and polyherbal extracts were ground together with $\mathrm{KBr}$ crystals in an agate mortar. The powders were pressed as a disc at the pressure of 15 tons using a hydraulic press. The scanning range was fixed at 500-4000 $\mathrm{cm}^{-1}$ with a resolution of $2 \mathrm{~cm}^{-1}$ [16-18].

Development of RP-HPLC method for simultaneous estimation for quercetin, ellagic acid and kaempferol

\section{Standards and reagents}

Quercetin (99\%), ellagic acid (97\%) and kaempferol (98\%) standards were procured from Natural Remedies Private Limited, Bangalore, India. HPLC grade Methanol and Formic acid (analytical grade) were purchased from Ranchem Private Limited. Millipore was used for Mill-Q-water. Analytical grade of chemical was purchased from Merck Specialities Private Limited, Mumbai.

\section{Instrumentations and chromatographic conditions}

Shimadzu LC-AD HPLC system equipped with CT0-20A controller and the column oven. A Rheodyne 7725 injection valve with $20 \mu \mathrm{l}$ loop volume and SPD-M20A photo-diode array detector and a Lap solution version 7.1 software was utilized for data acquisition and interpretation. Chromatographic separation was attained on RP $\mathrm{C}_{18}$ Phenomenex column $(250 \mathrm{~mm} \times 4.6 \mathrm{~mm}, 5 \mu \mathrm{m}$ pore size). The mixture of solvent $0.1 \%$ formic acid in water: methanol (40:60) at a flow rate of $0.8 \mathrm{ml} / \mathrm{min}$, with $20 \mathrm{~min}$ run time and the ambient column temperature was maintained and PDA detector was fixed at $208 \mathrm{~nm}$.

\section{Preparation of standards and sample stock solution}

Standard solution of quercetin, ellagic acid and kaempferol were prepared in the concentration range of 12.5 to $200 \mu \mathrm{g} / \mathrm{ml}$ in methanol for the calibration curve.

Methanolic stock solutions $(10 \mathrm{mg} / \mathrm{ml})$ of the compressed tablet were prepared and filtered through a $0.22 \mu \mathrm{m}$ PVDF membrane and stored at $-20^{\circ} \mathrm{C}$.

\section{Method validation}

\section{System suitability}

System suitability tests are a crucial part of the liquid chromatography technique. It guarantees that the system is working accurately. In the system suitability study, various parameters such as retention time, hypothetical plates and tailing factor were assessed. The system suitability method was accomplished by injecting a combination of standards in six repeats.

\section{Linearity}

The linearity of the proposed method was controlled by quantitative dilution of the standard arrangement of quercetin, ellagic acid and kaempferol to get the solution in the concentration range of $0-200$ $\mu \mathrm{g} / \mathrm{ml}$ for all markers. A calibration graph of peak area Vs concentration in $\mu \mathrm{g} / \mathrm{ml}$ was plotted for each of the three markers three-fold. The intercept, correlation coefficient and slope of the regression line were resolved.

\section{LOD and LOQ}

The LOD (limit of detection) and LOQ (limit of quantitation) signifies the concentration of analyte that would yield a signal-to-noise ratio of 3 for a limit of detection and 10 for a limit of quantitation. LOD and LOQ were determined utilizing the following formula $[19,20]$.

$$
\begin{gathered}
\text { LOD }=3 \delta S \\
\text { LOQ }=10 \delta S
\end{gathered}
$$

Where, $\delta=$ Standard deviation of response (peak area)

\section{$\mathrm{S}=$ Average of the slope of the calibration curve}

\section{System precision}

The system precision was checked by injecting six repeats of the blended standard solution to ensure that the analytical system is working appropriately.

\section{Method precision}

The method precision of the proposed technique was controlled by injecting six repeats of test and standard around the same day and on three different days to guarantee that the analytical technique is repeatable and reproducible.

\section{Accuracy}

The accuracy of this technique was analysed by calculating the recovery of quercetin, ellagic acid and kaempferol by standard addition technique. The known quantity of every standard drug solution was added to the pre-analyzed test relating to 80,100 and $120 \%$ of the label claim. At each level, three assurance were performed.

\section{Robustness}

Robustness is the proportion of method capacity to stay unaffected by little, however purposeful variation in technique boundaries, for example, mobile phase flow rate $( \pm 0.1 \mathrm{ml} / \mathrm{min})$, wavelength $\mathrm{nm}( \pm 1$ $\mathrm{nm})$ and column oven temperature $\left( \pm 1^{\circ} \mathrm{C}\right)$.

\section{RESULTS AND DISCUSSION}

The present study observes the design and development of solid oral polyherbal dosage form. The solid oral polyherbal dosage form, tablets were formulated using pregelatinized starch as a binder, MCC 102 act as diluent, sodium lauryl sulfate act as a lubricant, super disintegrants in a varying concentration such as crospovidone and Kyron T-314, magnesium stearate act as flow agent. For polyherbal formulation, a blend of drug and excipients were compressed using the direct compression method. The polyherbal extract and excipients mixed powder was compressed utilizing a direct compression technique.

\section{Preformulation studies}

The granules added to the polyherbal tablets were suitable. The precompression parameters like bulk density, true density, compressibility index, and Hausner's ratio were calculated. All the pre-formulation parameters are within the permissible limits and shown good flow properties and the data was shown in table 2 . The formulated granules were found to be constant and appropriate for direct compression of polyherbal tablets. 
Table 2: Evaluation parameter of granules

\begin{tabular}{ll}
\hline Evaluation parameters & Inference \\
\hline Bulk density & $0.641 \pm 0.003 \mathrm{~g} / \mathrm{ml}$ \\
Tapped density & $0.855 \pm 0.004 \mathrm{~g} / \mathrm{ml}$ \\
Percentage compressibility index & $25.35 \pm 0.471 \%$ \\
& (Passable) \\
Hausner's ratio & $1.337 \pm 0.002$ \\
& (Passable) \\
\hline
\end{tabular}

Values are expressed as mean $\pm \mathrm{SD}, \mathrm{n}=3$

\section{Evaluation of post compressional parameters}

The polyherbal tablets were prepared using the hydroalcoholic extract of A. racemosus, B. variegata, C. bonducella, S. asoca and $S$. racemosa are exposed to evaluation of various post compressional parameters like average weight variation, hardness, friability and disintegration time studies. The obtained data was within the range of pharmacopeial specifications and shown in table 3.

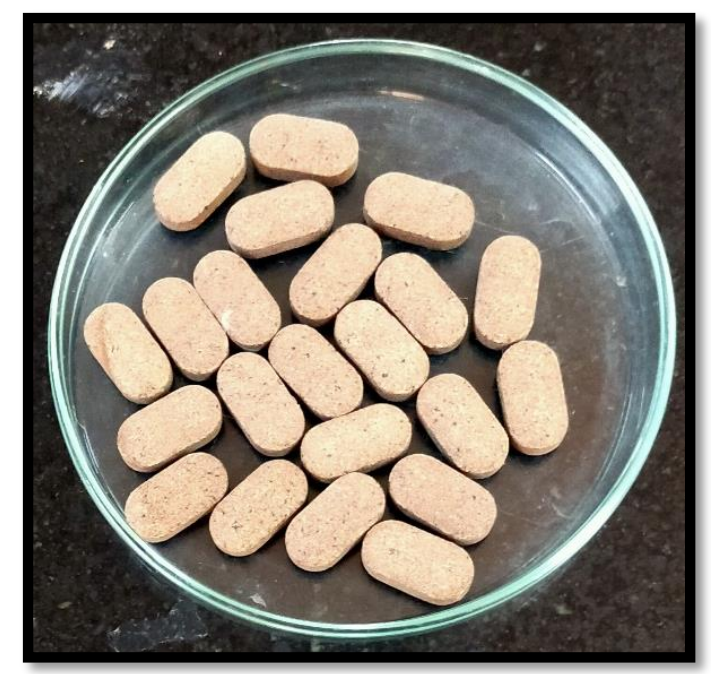

a
Table 3: Evaluation parameter of polyherbal tablets

\begin{tabular}{lll}
\hline S. No. & Parameters & Polyherbal formulation \\
\hline 1 & Average weight variation $(\mathrm{mg})$ & $752.67 \pm 1.247$ \\
2 & Hardness $\left(\mathrm{kg} / \mathrm{cm}^{2}\right.$ ) & $4.11 \pm 0.069$ \\
3 & Friability (\%) & $0.63 \pm 0.012$ \\
4 & Disintegration time (min) & $20.52 \pm 0.567$ \\
\hline
\end{tabular}

Values are expressed as mean \pm SD, $n=3$

\section{Characterization of polyherbal tablets}

The prepared polyherbal tablet formulation was subjected to evaluation like size, shape, color, appearance, thickness and diameter and was mentioned in table 4 . The formulated polyherbal tablets were non-sticky and look like high-quality in appearance. The imagined color and shape of all poly herbal tablets were detected directly by naked eyes (fig. 2). The thickness and diameter of polyherbal tablet formulation were calibrated using a digital vernier scale and depicted in table 4 .

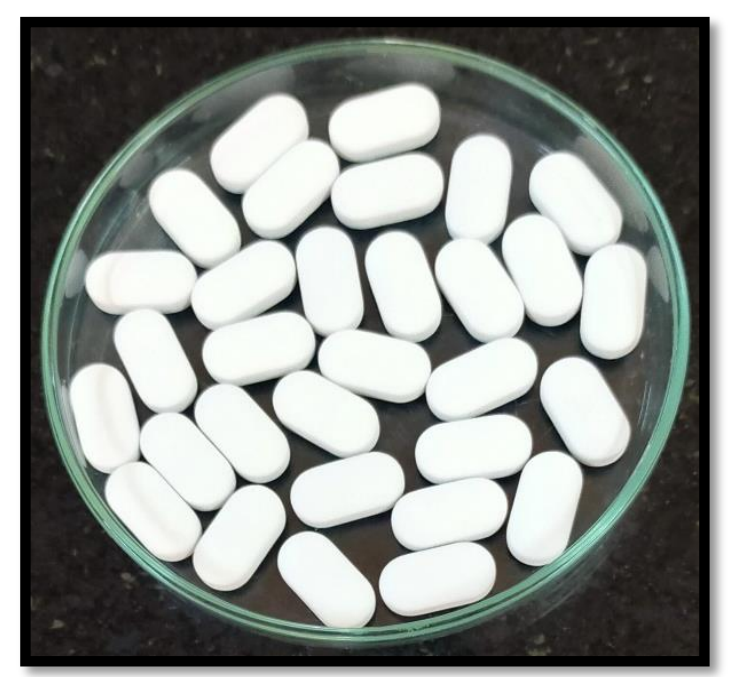

b

Fig. 2: (a) Polyherbal formulation before coating (b) Polyherbal formulation after coating

Table 4: Characterization of polyherbal formulation

\begin{tabular}{lll}
\hline S. No. & Parameters & Results \\
\hline 1 & Color & White \\
2 & Odor & Characteristic odor \\
3 & Shape & Oval \\
4 & Taste & Pleasant taste \\
5 & Size $(\mathrm{mm})$ & \\
& i) Thickness & $5.85 \pm 0.036$ \\
& ii) Diameter & $8.65 \pm 0.041$ \\
\hline
\end{tabular}

Values are expressed as mean $\pm \mathrm{SD}, \mathrm{n}=3$

\section{Optimized chromatographic condition}

The developed method was finally optimized with the following chromatographic conditions mobile phase comprising of $0.1 \%$ formic acid: methanol in a proportion of 40:60 v/v. The investigation was done in an isocratic elution mode utilizing a stream pace of $1.0 \mathrm{ml} / \mathrm{min}$, at $25{ }^{\circ} \mathrm{C}$ and identification was completed at $254 \mathrm{~nm}$ and $365 \mathrm{~nm}$. The Rt (retention time) of quercetin, ellagic acid, and kaempferol in the standard were discovered to be 4.86, 6.96 and $10.01 \mathrm{~min}$, respectively as shown in (fig. 3a). Quantification of the selected biomarker in the polyherbal formulation was done with the regression equation.
The results of the marker present in the polyherbal tablet are summarized in table 5 .

\section{Quantification of marker compounds in polyherbal formulation}

The chemical markers were identified and quantified in polyherbal formulation concerning quercetin, ellagic acid and kaempferol. The chromatograms of quercetin, ellagic acid and kaempferol showed efficient separation of the three compounds. Polyherbal formulation contained quercetin $(0.093 \pm 0.002 \mathrm{ng} / \mathrm{g})$, ellagic acid $(0.047 \pm 0.001$ $\mathrm{ng} / \mathrm{g})$ and kaempferol $(0.035 \pm 0.003 \mathrm{ng} / \mathrm{g})$. Every sample was completed in triplicate and the standard and sample chromatograms were shown in fig. $3 \mathrm{~b}$ and summarized in table 5 . 
Table 5: Quantification of quercetin, ellagic acid, and kaempferol in Polyherbal formulation by RP-HPLC method.

\begin{tabular}{|c|c|c|c|c|c|c|c|}
\hline \multicolumn{2}{|c|}{ Formulation } & \multicolumn{2}{|c|}{ Quercetin (ng/g) } & \multicolumn{2}{|c|}{ Ellagic acid (ng/g) } & \multicolumn{2}{|c|}{ Kaempferol (ng/g) } \\
\hline \multicolumn{2}{|c|}{ Polyherbal formulation } & \multicolumn{2}{|c|}{$0.093 \pm 0.002$} & \multicolumn{2}{|c|}{$0.047 \pm 0.001$} & \multicolumn{2}{|c|}{$0.035 \pm 0.003$} \\
\hline \multicolumn{8}{|c|}{ Values are expressed as mean $\pm S D, n=3$} \\
\hline \multicolumn{4}{|c|}{$\begin{array}{l}\text { Method validation } \\
\text { The developed reverse phase-HPLC technique was validated and } \\
\text { evaluated by determining the range and accuracy, linearity, } \\
\text { precision, LOQ and LOD [21]. The method was also evaluated for } \\
\text { qualitative analysis by considering the precision and selectivity of } \\
\text { an eluted chemical marker. Repeatability was achieved with a high } \\
\text { concentration of standards and extracts. Accuracy, linearity, } \\
\text { precision, LOQ and LOD were assessed for the quantification of } \\
\text { markers. The determination of LOD and LOQ were } 11.86 \text { and } 35.95\end{array}$} & \multicolumn{4}{|c|}{$\begin{array}{l}\mu \mathrm{g} / \mathrm{ml} \text { for quercetin and } 2.63 \text { and } 7.98 \mu \mathrm{g} / \mathrm{ml} \text { for ellagic acid, } 5.28 \\
\text { and } 16.00 \text { for kaempferol, correspondingly. The linearity of three } \\
\text { markers was obtained with concentrations versus peak areas in } \\
\text { the concentration range of } 0-200 \mu \mathrm{g} / \mathrm{ml} \text { and } \mathrm{R}^{2} \text { was higher than } \\
0.99 \text { (fig. } 4 \text { and table } 6 \text { ) [22]. } 97.02-102.5 \% \text { of recovery of the } \\
\text { compounds displayed an acceptable accuracy. The relative } \\
\text { standard deviation (RSD) of all compounds was less than } 2 \% \text {, a } \\
\text { representative for high repeatability (table } 7 \text { ). Precision and } \\
\text { intermediate precision have a very low coefficient of variation } \\
\text { reveals the method is precise (table } 8 \text { ). }\end{array}$} \\
\hline Compounds & $\begin{array}{l}\text { Concentration } \\
\text { range }(\mu \mathrm{g} / \mathrm{ml})\end{array}$ & Rt (min) & Reg & equation & $\mathbf{R}^{2}$ & LOD $(\mu \mathrm{g} / \mathrm{ml})$ & LOQ $(\mu \mathrm{g} / \mathrm{ml})$ \\
\hline Quercetin & $0-200$ & $4.864 \pm 0.005$ & $y=$ & 346872 & 0.999 & 11.86 & 35.95 \\
\hline Ellagic acid & $0-200$ & $6.962 \pm 0.008$ & & 77053 & 0.9986 & 2.63 & 7.98 \\
\hline Kaempferol & $0-200$ & $10.016 \pm 0.003$ & & 144665 & 0.9979 & 5.28 & 16.00 \\
\hline
\end{tabular}

Values are expressed as mean $\pm \mathrm{SD}, \mathrm{n}=3$

Table 7: Recovery study of quercetin, ellagic acid and kaempferol present in polyherbal formulation

\begin{tabular}{llll}
\hline Compounds & Amount added (mg/g) & Recorded amount (mg) & \% Recovery rate \\
\hline \multirow{2}{*}{ Quercetin } & 80 & $0.982 \pm 0.011$ & $98.283 \pm 1.197$ \\
& 100 & $0.978 \pm 0.007$ & $97.84 \pm 0.761$ \\
Ellagic acid & 120 & $0.989 \pm 0.009$ & $99.923 \pm 0.233$ \\
& 80 & $1.017 \pm 0.007$ & $101.73 \pm 0.739$ \\
& 100 & $1.025 \pm 0.01$ & $102.506 \pm 1.139$ \\
Kaempferol & 120 & $1.003 \pm 0.016$ & $1.951 \pm 0.001$ \\
& 80 & $1.005 \pm 0.002$ & $101.04 \pm 0.04 \pm 0.441$ \\
& 100 & $1.006 \pm 0.006$ & $99.7 \pm 0.635$ \\
\hline
\end{tabular}

Values are expressed as mean $\pm \mathrm{SD}, \mathrm{n}=3$
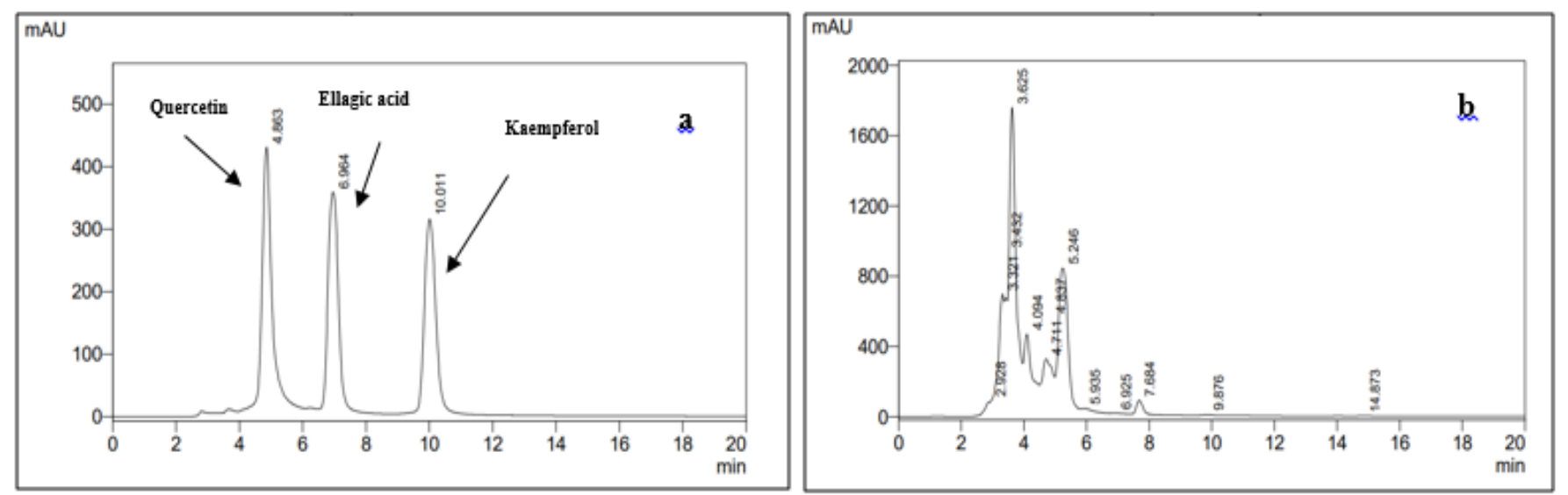

Fig. 3: Chromatogram of quercetin, ellagic acid, kaempferol standard (a) and Chromatogram of polyherbal tablet formulation (b)

Table 8: Precision of the intra-day and inter-day HPLC measurement for quercetin, ellagic acid and kaempferol in Polyherbal formulation

\begin{tabular}{llll}
\hline Compounds & Intra-day & \multicolumn{1}{l}{ Inter-day } \\
\cline { 2 - 4 } & Contents (\% w/w) & RSD (\%) & Contents (\% w/w) \\
\hline Quercetin & $0.112 \pm 0.05$ & 0.50 & $0.115 \pm 0.04$ \\
Ellagic acid & $0.056 \pm 0.04$ & 1.33 & $0.059 \pm 0.08$ \\
Kaempferol & $0.047 \pm 0.01$ & 0.27 & $0.046 \pm 0.08$ \\
\hline
\end{tabular}

Values are expressed as mean $\pm \mathrm{SD}, \mathrm{n}=3$ 

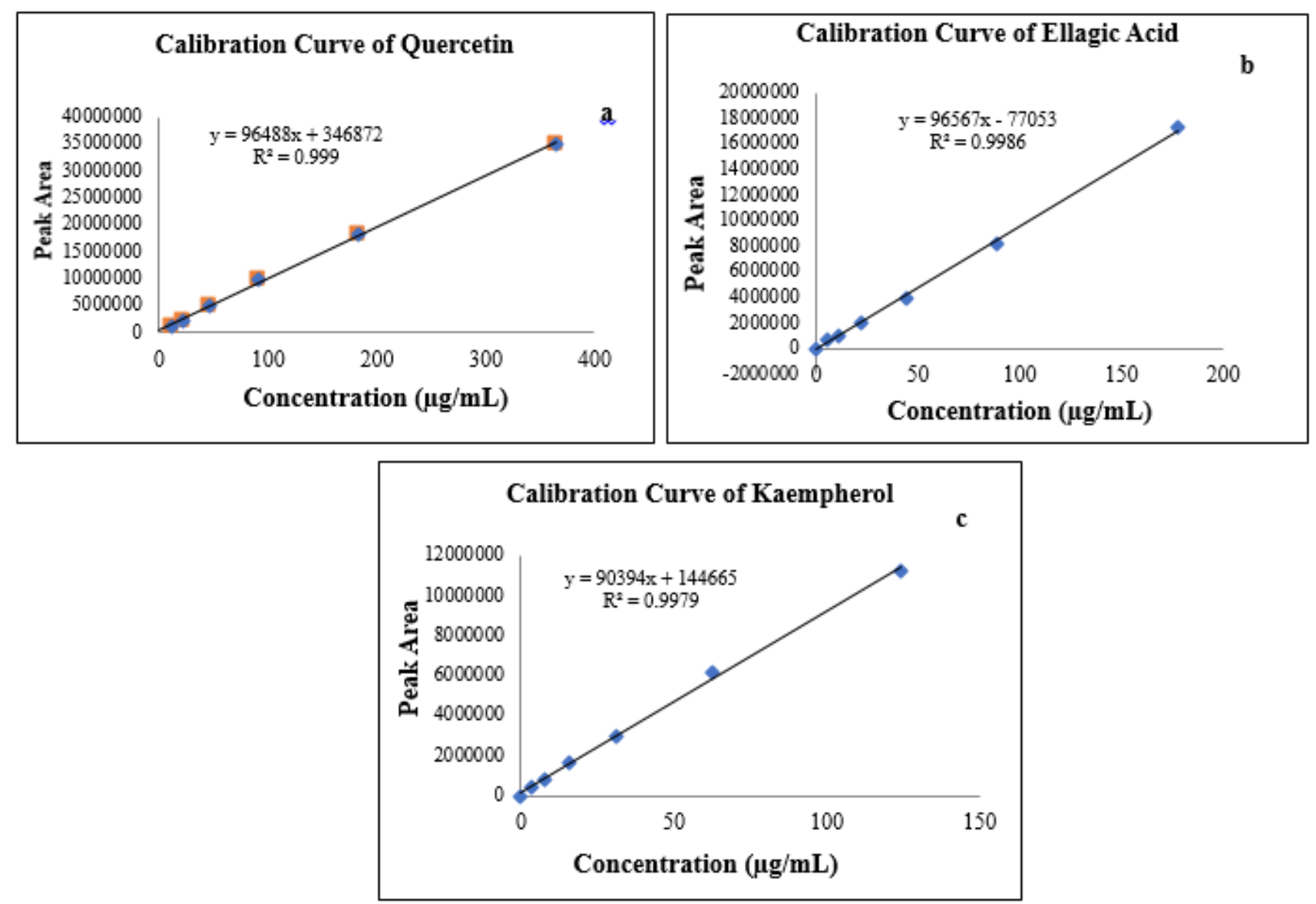

Fig. 4: Calibration curve of (a) Quercetin (b) Ellagic acid (c) Kaempferol

\section{FT-IR reports}

From the FT-IR Spectroscopy reports (fig. 5), was it clear that all the extracts are rich in phytochemicals such as alkaloids, flavonoids, Phyto-steroids, glycosides and phenolic compounds. The report also shows that there is no interactions and also the drug and excipients are compatible to develop a stable polyherbal formulation. The present FT-IR fingerprint study of $A$. racemosus, B. variegata, $C$. bonducella, S. asoca, S. racemosa, excipients and polyherbal formulation were extracted to characterize the FT-IR fingerprint [23].

The IR spectrum of Asparagus racemosus (fig. 5a) was detected and determined the characteristics of functional groups through different peaks (table 9) i.e., $3108.64 \mathrm{~cm}^{-1}$ for alkene group (C-H stretching), $2103.13 \mathrm{~cm}^{-1}$ for alkyne group ( $\mathrm{C} \equiv \mathrm{C}$ stretching), $1625.35 \mathrm{~cm}^{-1}$ for $\alpha, \beta$ unsaturated ketone ( $\mathrm{C}=\mathrm{C}$ stretching), $1405.51 \mathrm{~cm}^{-1}$ for the phenolic group (C-0 stretching), $1025.15 \mathrm{~cm}^{-1}$ for aromatic amine group (C-N vibrations), $752.11 \mathrm{~cm}^{-1}$ for an aromatic group (C-H bending) and halo compound group found at $632.52 \mathrm{~cm}^{-1}$.

The IR spectrum of Bauhinia variegata (fig. 5b) was detected and determined the characteristics of functional groups through different peaks (table 9) i.e., $3331.95 \mathrm{~cm}^{-1}$ for amide group ( $\mathrm{N}-\mathrm{H}$ stretching), $2944.52 \mathrm{~cm}^{-1}$ for alkane group (C-H stretching), $2349.40 \mathrm{~cm}^{-1}$ for the carboxylic group $\left(\mathrm{O}=\mathrm{C}=0\right.$ stretching), $2106.25 \mathrm{~cm}^{-1}$ for alkyne group ( $\mathrm{C} \equiv \mathrm{C}$ stretching), $1628.06 \mathrm{~cm}^{-1}$ for an aromatic group ( $\mathrm{C}=\mathrm{C}$ stretching), $1401.79 \mathrm{~cm}^{-1}$ for fluro compound (C-F stretching), $1120.46 \mathrm{~cm}^{-1}$ for secondary alcohol (C-O stretching), $1032.02 \mathrm{~cm}^{-1}$ for sulfoxide group ( $\mathrm{S}=0$ stretching) and $848.14 \mathrm{~cm}^{-1}$ for halo compound.

The IR spectrum of Caesalpinia bonducella (fig. 5c) was detected and determined the characteristics of functional groups through different peaks (table 9) i.e., $3148.48 \mathrm{~cm}^{-1}$ for an aliphatic primary amino group ( $\mathrm{N}-\mathrm{H}$ stretching), $2924.08 \mathrm{~cm}^{-1}$ for alkane group (C-H stretching), $2112.32 \mathrm{~cm}^{-1}$ for alkyne group ( $\mathrm{C} \equiv \mathrm{C}$ stretching), 1641.78 $\mathrm{cm}^{-1}$ for alkene group ( $\mathrm{C}=\mathrm{C}$ stretching), $1410.45 \mathrm{~cm}^{-1}$ for the phenolic group (C-O stretching) and secondary alcohol group (C-O stretching) found at $1121.21 \mathrm{~cm}^{-1}$.

The IR spectrum of Saraca asoca (fig. 5d) was detected and determined the characteristics of functional groups through different peaks (table 9) i.e., $3196.56 \mathrm{~cm}^{-1}$ for alcohol group $(\mathrm{O}-\mathrm{H}$ Stretching), $2288.73 \mathrm{~cm}^{-1}$ for alkyne group (C $\equiv \mathrm{C}$ stretching), $2117.04 \mathrm{~cm}^{-1}$ for alkyne group ( $\mathrm{C} \equiv \mathrm{C}$ stretching), $1617.00 \mathrm{~cm}^{-1}$ for an aromatic group $\left(\mathrm{C}=\mathrm{C}\right.$ stretching), $1400.93 \mathrm{~cm}^{-1}$ for fluro compound group (C-F stretching), $1115.92 \mathrm{~cm}^{-1}$ for secondary alcohol (C-O stretching), $1037.71 \mathrm{~cm}^{-1}$ for sulfoxide (S=0 stretching) and halo compound group at $753.85 \mathrm{~cm}^{-1}$.

Table 9: Observed IR peaks of polyherbal formulation and their interpretation

\begin{tabular}{llll}
\hline Samples prepared & Observed peak cm $\mathbf{- 1}^{\mathbf{1}}$ & Group present & Interpretation \\
\hline Asparagus racemosus & 3108.64 & Alkene & C $-\mathrm{H}$ Stretching \\
& 2103.13 & Alkyne group & C $\mathrm{C}$ Stretching \\
& 1625.35 & $\alpha, \beta$-Unsaturated ketone & C=C Stretching \\
& 1405.51 & Phenols & C Stretching \\
& 1025.15 & Aromatic amine & C-N Vibrations \\
\hline
\end{tabular}




\begin{tabular}{|c|c|c|c|}
\hline & 632.52 & Halo compound & $\mathrm{C}-\mathrm{Br}$ Stretching \\
\hline \multirow[t]{9}{*}{ Bauhinia variegata } & 3331.95 & Amide group & $\mathrm{N}-\mathrm{H}$ Stretching \\
\hline & 2944.52 & Alkane & C-H Stretching \\
\hline & 2349.40 & Carboxylic group & $\mathrm{O}=\mathrm{C}=0$ Stretching \\
\hline & 2106.25 & Alkyne group & $\mathrm{C} \equiv \mathrm{C}$ Stretching \\
\hline & 1628.06 & Aromatic & $\mathrm{C}=\mathrm{C}$ Stretching \\
\hline & 1401.79 & Fluro compound & $\mathrm{C}-\mathrm{F}$ Stretching \\
\hline & 1120.46 & Secondary alcohol & C-O Stretching \\
\hline & 1032.02 & Sulfoxide & $S=0$ Stretching \\
\hline & 848.14 & Halo compound & $\mathrm{C}-\mathrm{Cl}$ Stretching \\
\hline \multirow[t]{6}{*}{ Caesalpinia bonducella } & 3148.48 & Aliphatic primary amine & $\mathrm{N}-\mathrm{H}$ Stretching \\
\hline & 2924.08 & Alkane & C-H Stretching \\
\hline & 2112.32 & Alkyne & $\mathrm{C} \equiv \mathrm{C}$ Stretching \\
\hline & 1641.78 & Alkene & $\mathrm{C}=\mathrm{C}$ Stretching \\
\hline & 1410.45 & Phenolic group & $\mathrm{C}-\mathrm{O}$ Stretching \\
\hline & 1121.21 & Secondary alcohol & C-O Stretching \\
\hline \multirow[t]{7}{*}{ Saraca asoca } & 3196.56 & Alcohol & $\mathrm{O}-\mathrm{H}$ Stretching \\
\hline & 2288.73 & Alkyne & $\mathrm{C} \equiv \mathrm{C}$ Stretching \\
\hline & 2117.04 & Alkyne & $\mathrm{C} \equiv \mathrm{C}$ Stretching \\
\hline & 1617.00 & Aromatic & $\mathrm{C}=\mathrm{C}$ Stretching \\
\hline & 1115.92 & Secondary alcohol & $\mathrm{C}-0$ Stretching \\
\hline & 1037.71 & Sulfoxide & $S=0$ Stretching \\
\hline & 753.85 & Halo compound & $\mathrm{C}-\mathrm{Br}$ Stretching \\
\hline \multirow[t]{5}{*}{ Symplocos racemosa } & 3861.34 & Alcohol & $0-\mathrm{H}$ Stretching \\
\hline & 2093.98 & Isothiocyanates & $\mathrm{N}=\mathrm{C}=\mathrm{S}$ Stretching \\
\hline & 1637.32 & Alkene & $\mathrm{C}=\mathrm{C}$ Stretching \\
\hline & 1408.83 & Sulfate & $S=0$ Stretching \\
\hline & 748.07 & Halo compound & $\mathrm{C}-\mathrm{Br}$ Stretching \\
\hline \multirow{7}{*}{$\begin{array}{l}\text { Excipients mixed (pregelatinished } \\
\text { starch+MCC } \\
\text { 102+crospovidone+SLS+colloidal } \\
\text { silicon dioxide alum+magnesium } \\
\text { stearate+kyron T-314) }\end{array}$} & 3152.48 & Aliphatic primary amine & $\mathrm{N}-\mathrm{H}$ Stretching \\
\hline & 2929.00 & Alkane & $\mathrm{C}-\mathrm{H}$ Stretching \\
\hline & 2276.19 & Alkyne & $\mathrm{C} \equiv \mathrm{C}$ Stretching \\
\hline & 1651.58 & Alkene & $\mathrm{C}=\mathrm{C}$ Stretching \\
\hline & 1564.87 & Aromatic & $\mathrm{C}=\mathrm{C}$ Bending \\
\hline & 1408.62 & Alkane & $\mathrm{C}-\mathrm{H}$ Bending \\
\hline & 620.03 & Halo compound & $\mathrm{C}-\mathrm{Cl}$ Stretching \\
\hline \multirow{5}{*}{$\begin{array}{l}\text { Polyherbal formulation without } \\
\text { excipients mixed }\end{array}$} & 3142.10 & Alkenyl & $\mathrm{C}-\mathrm{H}$ Stretching \\
\hline & 2274.92 & Alkyne & $\mathrm{C} \equiv \mathrm{C}$ Stretching \\
\hline & 1636.17 & Amide group & $\mathrm{C}=0$ Stretching \\
\hline & 1402.55 & Alkanes & $\mathrm{C}-\mathrm{H}$ Bending \\
\hline & 615.62 & Halo compound & $\mathrm{C}-\mathrm{Cl}$ Stretching \\
\hline \multirow[t]{7}{*}{ Polyherbal formulation } & 3167.27 & Amide group & $\mathrm{N}-\mathrm{H}$ Stretching \\
\hline & 2933.82 & Alkane group & $\mathrm{C}-\mathrm{H}$ Stretching \\
\hline & 2135.30 & Alkyne group & $\mathrm{C} \equiv \mathrm{C}$ Stretching \\
\hline & 1640.15 & Amine group & $\mathrm{N}-\mathrm{H}$ Bending \\
\hline & 1406.00 & Ester group & $\mathrm{C}-0$ Stretching \\
\hline & 1113.79 & Alcohol group & $\mathrm{O}-\mathrm{H}$ Bending \\
\hline & 754.28 & Aromatic group & $\mathrm{C}-\mathrm{H}$ Bending \\
\hline
\end{tabular}

The IR spectrum of Symplocos racemosa (fig. 5e) was detected and determined the characteristics of functional groups through different peaks (table 9) i.e., $3861.34 \mathrm{~cm}^{-1}$ for the alcohol group $(\mathrm{O}-\mathrm{H}$ stretching), $2093.98 \mathrm{~cm}^{-1}$ for isothiocyanates group $(\mathrm{N}=\mathrm{C}=\mathrm{S}$ Stretching), $1637.32 \mathrm{~cm}^{-1}$ for alkene group (C=C stretching), 1408.83 $\mathrm{cm}^{-1}$ for sulfate group ( $\mathrm{S}=0$ stretching) and halo compound group (CBr stretching) at $748.07 \mathrm{~cm}^{-1}$.

The IR spectrum of excipients mixed (fig. $5 f$ ) in contains pregelatinized starch+MCC 102+crospovidone+SLS+colloidal silicon dioxide alum+magnesium stearate+kyron T-314 was detected and determined the characteristics of functional groups through different peaks (table 9) i.e., $3152.48 \mathrm{~cm}^{-1}$ for aliphatic primary amine $(\mathrm{O}-\mathrm{H}$ stretching), $2276.19 \mathrm{~cm}^{-1}$ for alkyne group (C $\equiv \mathrm{C}$ stretching), $1651.58 \mathrm{~cm}^{-1}$ for alkene group ( $\mathrm{C}=\mathrm{C}$ stretching), $1564.87 \mathrm{~cm}^{-1}$ for aromatic group and $111.66,756.98,620.03 \mathrm{~cm}^{-1}$ for halo compound.
The IR spectrum of polyherbal formulation without excipients mixed (fig. 5g) was detected and determined the characteristics of functional groups through different peaks (table 9) i.e., $3142.10 \mathrm{~cm}^{-1}$ for the alkenyl group (C-H stretching), $2274 \mathrm{~cm}^{-1}$ for alkyne group ( $\mathrm{C} \equiv \mathrm{C}$ stretching), $1636.17 \mathrm{~cm}^{-1}$ for amide group ( $\mathrm{C}=\mathrm{C}$ stretching), $1402.55 \mathrm{~cm}^{-1}$ for alkane group (C-H bending), 111.722, 754.30, $615.62 \mathrm{~cm}^{-1}$ for halo compound.

The IR spectrum of polyherbal formulation (fig. 5h) was detected and determined the characteristics of functional groups through different peaks (table 9) i.e., $3167.27 \mathrm{~cm}^{-1}$ for amide group (N-H stretching), $2933.82 \mathrm{~cm}^{-1}$ for alkane group (C-H stretching), 2135.30 $\mathrm{cm}^{-1}$ for alkyne group ( $\mathrm{C} \equiv \mathrm{C}$ stretching), $1640.15 \mathrm{~cm}^{-1}$ for an amino group ( $\mathrm{N}-\mathrm{H}$ bending), $1406.00 \mathrm{~cm}^{-1}$ for ester group (C-O stretching), $1113.79 \mathrm{~cm}^{-1}$ for alcohol group (O-H bending) and aromatic group (C-H bending) at $754.28 \mathrm{~cm}^{-1}$. 

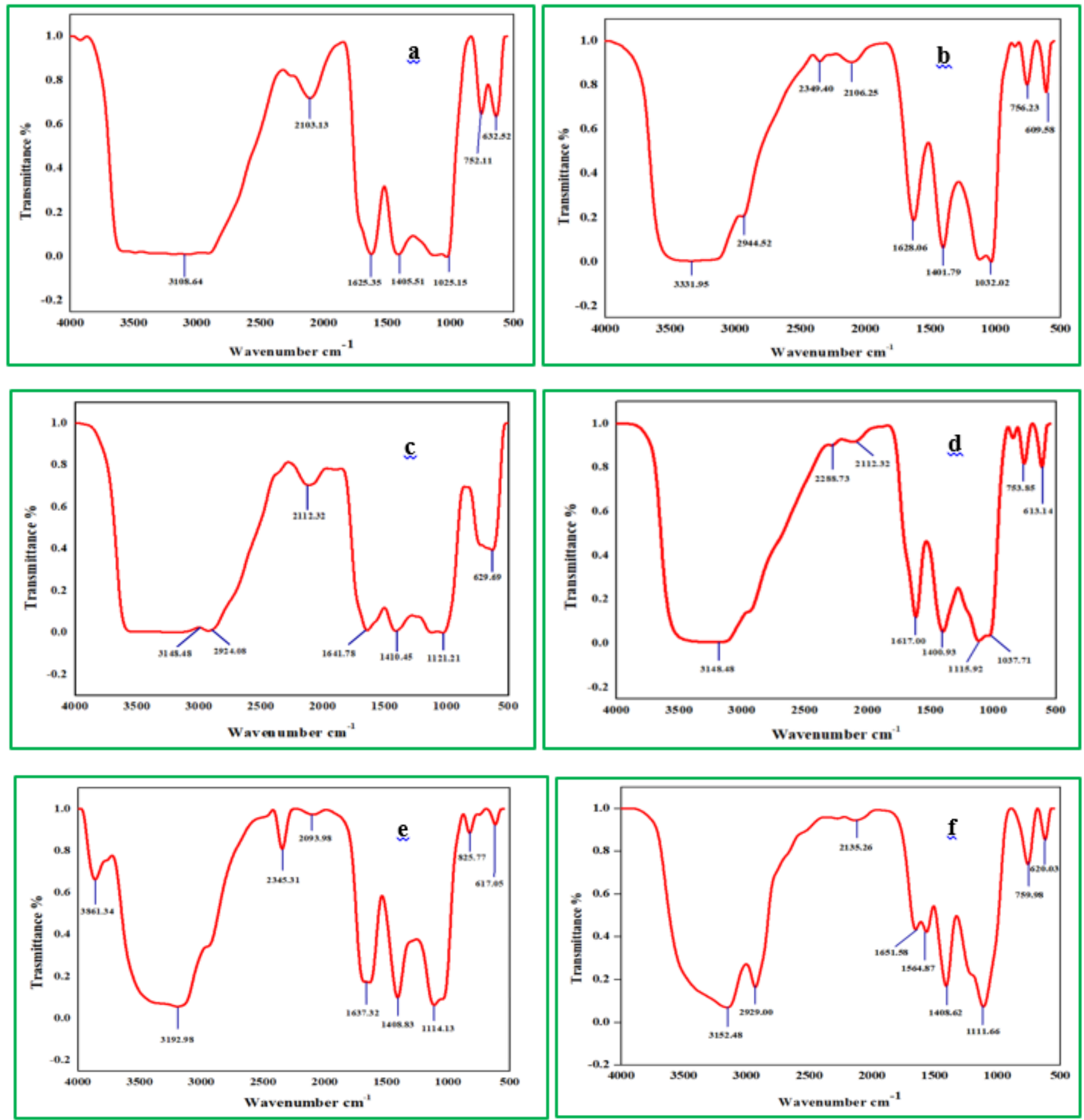

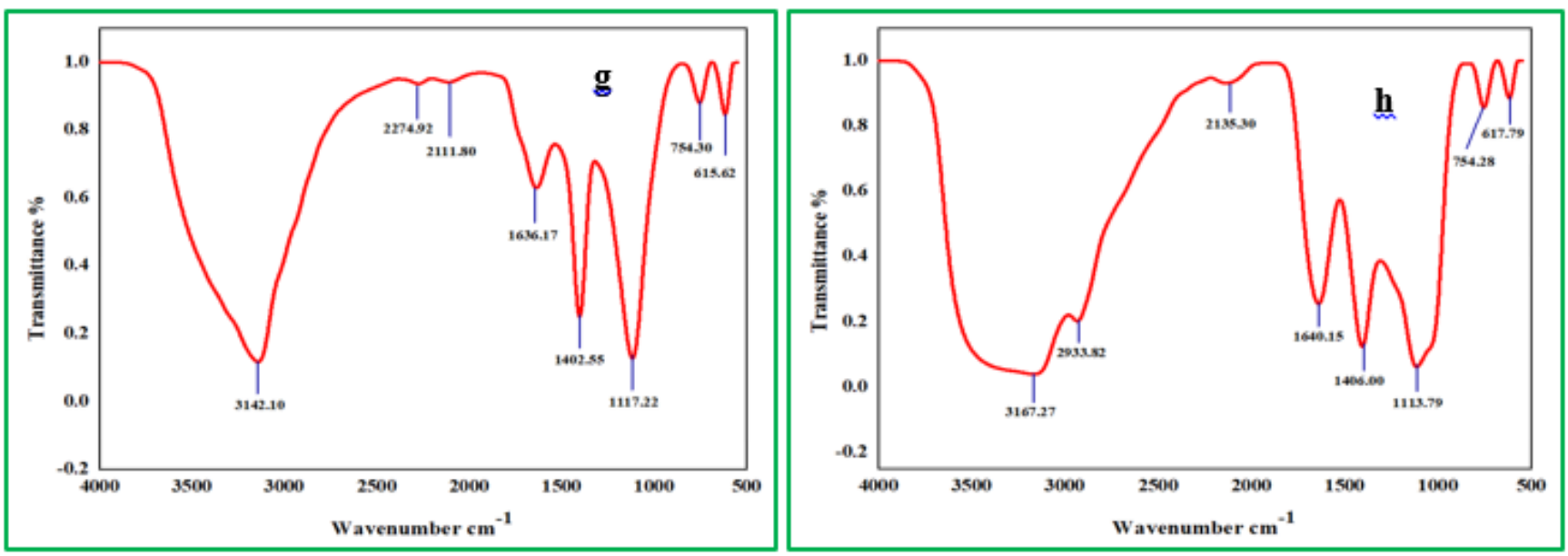

Fig. 5: IR Spectrum-Hydroalcoholic extract of (a) Asparagus racemosus (b) Bauhinia variegata (c) Caesalpinia bonducella (d) Saraca asoca (e) Symplococus racemosus (f) Excipients mixed (Pregelatinished starch+MCC 102+Crospovidone+SLS+ Colloidal silicon dioxide alum+ Magnesium stearate+ Kyron T-314) (g) PHF Without excipients mixed (h) PHF with excipients mixed

\section{CONCLUSION}

The outcomes from the pre-formulation studies include bulk density, tapped density, compressibility index and Hausner's ratio demonstrated that the powder granules possess good flow properties. The precompression properties of polyherbal formulation were determined for the average weight variation, hardness, friability and disintegration which falls within the acceptable limit. The FTIR spectrum report reveals the noninterference of any chemical interaction between the polyherbal extract and the excipients utilized in the polyherbal formulation. The developed RP-HPLC method for simultaneous estimation of quercetin, ellagic acid and kaempferol in the developed polyherbal formulation is novel, simple, rapid, accurate and precise. The optimized method was authenticated as per ICH guidelines and the results gained were within the acceptable limits. The optimized method delivers ideal separation in such a way that, gives better resolution and avoids the merging of peaks. Hence, the proposed method was found to be good and can be applied for repetitive qualitative and quantitative analysis of quercetin, ellagic acid and kaempferol in medicinal plants as well as polyherbal formulations.

\section{ACKNOWLEDGMENT}

The authors are thankful to the management, SRM Institute of Science and Technology for providing instrumentation facilities to complete the study.

\section{FUNDING}

Nil

\section{AUTHORS CONTRIBUTORS}

Both the authors have contributed equally.

\section{CONFLICT OF INTERESTS}

The authors declare no conflict of interest.

\section{REFERENCES}

1. Gilhotra UK, Mohan G, Christina AJM. Antilithiatic activity of poly-herbal formulation tablets by in vitro method. J Appl Pharm Sci 2013;3:43-8.

2. Kabayundo J, Muganga R, Humura F, Abila DB, Micheal AI. The impact of herbal medicines uses in patients under highly active antiretroviral therapy in rwanda. Int J Pharm 2020;10:1-10.

3. Karole S, Shrivastava S, Thomas S, Soni B, Khan S, Dubey J, et al. Polyherbal formulation concept for synergic action: a review. J Drug Delivery Ther 2019;9:453-66.

4. Chimagave SS, Jalalpure SS, Kurangi BK. Preparation and development of polyherbal formulation of medicinal plants for antiarthritic activity. Indian J Health Sci Biomed Res 2020;13:120-6.

5. Awasthi H, Mani D, Nath R, Nischal A, Usman K, Khattri S. Standardization, preparation and evaluation of an ayurvedic polyherbal formulation in capsule dosage form suitable for use in clinical trials. Indo Am J Pharm Res 2014;4:4093-39.

6. Majumder P, Paridhavi M. Physiocochemical standardization and formulation development of poly-herbal tablet for diabetes. Br J Pharm Res 2016;12:1-17.

7. Hamrah KTKA, Al-Shaibani AJN, Al-Edresi SS, Al-Gburi KMH. A comparative study of quality control testing on candesartan cilexetil conventional tablets in Iraq. Int J Appl Pharm 2020;12:103-8.

8. Odani N, Mohan S, Kato E, Feng H, Li Y, Hossain MN, et al. Determining the effect of photodegradation on film coated nifedipine tablets with terahertz-based coating thickness measurements. Eur J Pharm Biopharm 2019;145:35-41.

9. Shaikh S, Jain V. Development and validation of novel RP-HPLC method for the simultaneous estimation of ellagic acid and quercetin in an ayurvedic formulation. Int J Appl Pharm 2018;10:111-6.

10. Nuzhat Qureshi, Raghvendra Dubey, Nilesh Kumar Pathak. Polyherbal preparation and comparative studies on diet-induced hyperlipidemia. Asian J Pharm Clin Res 2019;12:190-6.

11. Agnihotri A, Singh V. Formulation development and evaluation of antidiabetic polyherbal tablet. J Pharm Innov 2014;3:1-3.

12. Maurya H, Kumar T. Formulation, standardization, and evaluation of polyherbal dispersible tablet. Int J Appl Pharm 2019;11:158-67.

13. Navamanisubramanian $\mathrm{R}$, Nerella $\mathrm{R}$, Seetharaman $\mathrm{S}$. Pharmacokinetic investigation to study the in vivo bioavailability of thiolated chitosan based repaglinide buccal tablets. Pharm Sci 2020;26:414-22.

14. Pamu Poornima, Karra Geetha, Pamu Sandhya. Evaluation of cetrizine hydrochloride-loaded orally disintegrating tablets for disintegration time and dissolution studies. Int J Pharm 2019;9:10-9.

15. Dinakaran SK, Sujiya B, Avasarala H. Profiling and determination of phenolic compounds in Indian marketed hepatoprotective polyherbal formulations and their comparative evaluation. J Ayurveda Integr Med 2018;9:3-12.

16. Vasanth MP, Purushotham KG. Screening of phytochemical analysis and in vitro bioactive of polyherbal formulation. Pharmacogn J 2020;12:1525-33.

17. Chandra Sekhar Naik D, Bharathi A, Basaveswara Rao MV. Design and formulation development of fast-dissolving tablets of ibuprofen using novel natural super disintegrant. Asian J Pharm Clin Res 2019;12:34-41. 
18. Nath J. Formulation and in vitro evaluation of curcumin loaded jackfruit seed starch nanoparticles. Int J Curr Pharm Res 2020;12:32-5.

19. Senthil Rajan D, Muruganathan G, Shivkumar K, Thangavel G. Development and validation of hplc method for simultaneous quantification of vasicine, glycyrrhizin and piperine in poly herbal cough syrup. Int J Curr Pharm Res 2020;12:15-9.

20. Bhat MH, Fayaz M, Kumar A, Dar AA, Jain AK. Chromatographic method for determination of the amino acid content in Dioscorea bulbifera L. tubers by RP-HPLC Pharm Sci 2019;25:65-9.
21. Yaripour S, Mohammadi A, Mousavi S, Esfanjani I, Arabzadeh N, Mozaffari S. Simultaneous determination of 2-nitrophenol and 4-nitrophenol in pharmaceutical industrial wastewater by electromembrane extraction coupled with HPLC-UV analysis. Pharm Sci 2019;25:57-64.

22. Ghosh VK, Bhope SG, Kuber VV, Gaikwad PS, Patil MJ. Development and validation of dissolution test method for andrographolide from film coated polyherbal tablet formulation. Int J Phar Pharm Sci 2012;4:307-12.

23. Zhu $\mathrm{H}$, Wang $\mathrm{Y}$, Liang $\mathrm{H}$, Chen $\mathrm{Q}$, Zhao $\mathrm{P}$, Tao J. Identification of portulaca oleracea L. from different sources using GC-MS and FT-IR spectroscopy. Talanta 2010;81:129-35. 